\title{
OVARIAN BLOODFLOW IN SHEEP DURING THE OESTROUS CYCLE
}

\author{
P. E. MATTNER AND G. D. THORBURN \\ C.S.I.R.O. Division of Animal Physiology, Ian Clunies Ross Animal Research Laboratory, \\ Prospect, N.S.W., Australia \\ (Received 28th January 1969)
}

It is uncertain whether ovarian bloodflow in ewes remains constant or varies with the stage of the oestrous cycle. In an experiment in which 'minimal estimates' of the ovarian steroid secretion rates were obtained, Short, McDonald \& Rowson (1963) cannulated the "major vein draining the corpus luteum or ripe Graafian follicle". The bloodflow rates obtained were lower in oestrous than in di-oestrous ewes. Moore, Brown \& Smythe (1965) using a similar technique did not find that the rates varied cyclically.

In the present study, seventeen Merino and five Corriedale ewes were used. They were 5 to 7 years old and had regularly exhibited oestrus at intervals of 17 days. Anaesthesia was induced and maintained with sodium pentobarbitone except on nine occasions when anaesthesia was maintained with fluothane. The abdomen was opened by a mid-ventral incision and 12,500 i.u. of heparin were given intravenously. A polyvinyl catheter was passed into each uteroovarian vein through an incision in a branch of the corresponding middle uterine vein. Each utero-ovarian vein was ligated below the end of the catheter. Tributaries of this vein, other than the ovarian veins, were also ligated so that only ovarian blood entered the catheter. Each catheter (length $9 \mathrm{~cm}$, internal diameter $2.0 \mathrm{~mm}$ ) was connected with $3.2-\mathrm{mm}$ internal diameter tubing to form a low-resistance collection system. Timed collections of blood, approximately $80 \mathrm{ml}$ from each ovary, were made simultaneously. The ligatures and catheters were then removed and the incised veins tied off. The abdomen was closed and the animal allowed to recover.

Collections were made on 2 successive days in twenty of the ewes. In twelve of these, the ovaries were removed and weighed after the second collection period. In individual ewes during the luteal phase, similar bloodflow rates were obtained at the two collections. Ovarian bloodflow during consecutive periods of sodium pentobarbitone-maintained and fluothane-maintained anaesthesia was similar in each of three ewes examined. Consequently the results from all animals were pooled.

For Days $0,1,2,15$ and 16 of the oestrous cycle (Text-fig. 1), the mean bloodflow $( \pm$ S.E.) was $2.91 \pm 0.25 \mathrm{ml} / \mathrm{min}$ in ovaries with pre-ovulatory follicles or recent ovulation points and $3.05 \pm 0.32 \mathrm{ml} / \mathrm{min}$ in the contralateral 'inactive' ovaries. The rates during Days 3 to 14 , inclusive, of $7.80 \pm 0.48 \mathrm{ml} / \mathrm{min}$ in ovaries with corpora lutea and $6.59 \pm 0.42 \mathrm{ml} / \mathrm{min}$ in those without corpora 
lutea, were significantly greater than the former rates $(P<0.001$ by Student's $t$-test). Ovaries that ovulated and their contralateral ovaries that did not ovulate during a cycle had similar rates of bloodflow per gram of tissue. The mean value for all ovaries was $3 \cdot 40 \pm 0 \cdot 28 \mathrm{ml} / \mathrm{g} / \mathrm{min}$ in six ewes during Days 0 , $1,2,15$ and 16 and $6 \cdot 62 \pm 0.71 \mathrm{ml} / \mathrm{g} / \mathrm{min}$ in six other ewes during Days 3 to 14 .

In a separate study (Thorburn \& Mattner, unpublished), ovarian bloodflow was measured in several unanaesthetized ewes by means of exteriorized reentrant catheters carrying only ovarian blood. The catheters remained patent for only a few days. As the flow rates in the luteal phase were similar to those found in the present study, anaesthesia apparently has little effect on ovarian bloodflow in sheep.

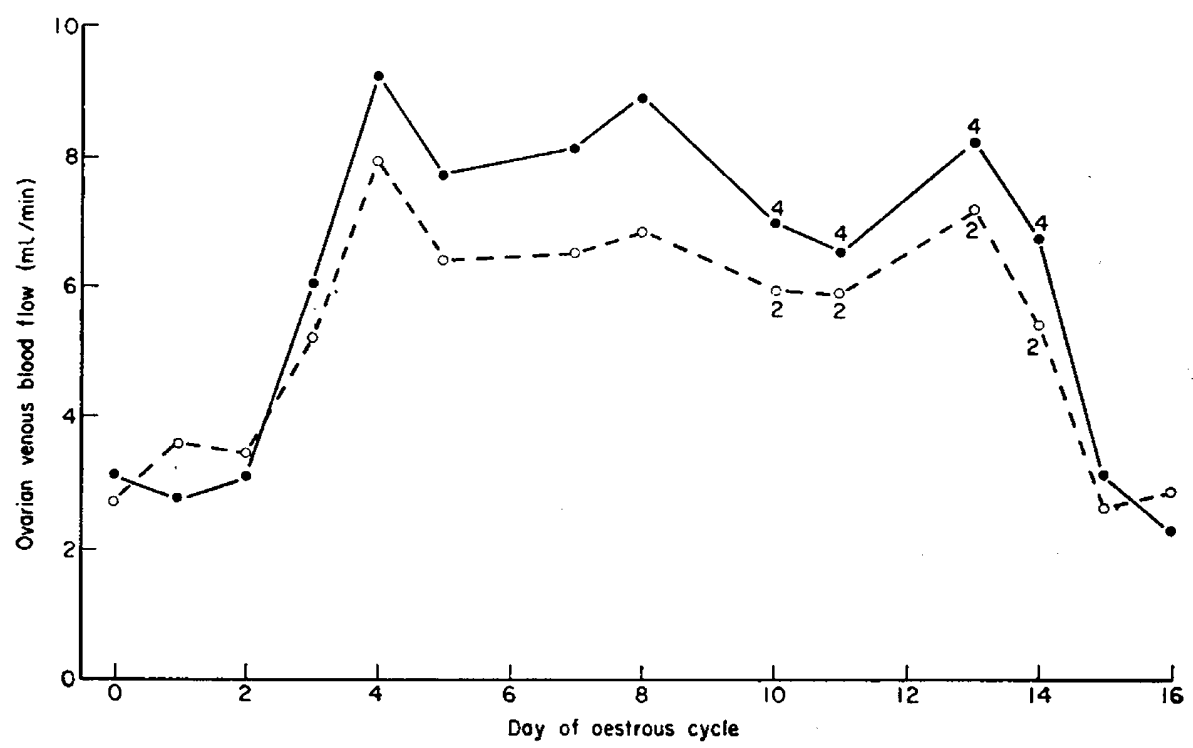

Texr-Fig. 1. Ovarian bloodflow in sheep during the oestrous cycle. Day $0=$ day of oestrus. Each point represents the mean for three ovaries except where otherwise indicated. Q, Ovaries with a pre-ovulatory follicle (Day 0 ) or a corpus luteum (Days 1 to 16$)$; 0 , contralateral 'inactive' ovaries.

The finding that ovaries with or without corpora lutea had similar cyclic variation in bloodflow suggests that a humoral or a nervous control mechanism determines the bloodflow to the ovaries and overrides the local effects of a corpus luteum. Since the rate of ovarian bloodflow was elevated during the luteal phase of the cycle, control by progesterone may be indicated. Levels of progesterone circulating in the blood may control ovarian bloodflow by affecting the tone of the ovarian vessels. Thus, it has been shown that progesterone can reduce the vasoconstrictor effects of vasopressin, oxytocin or angiotensin (Lloyd, 1959; Hettiaratchi \& Pickford, 1968).

The functional significance of the relatively high rate of ovarian bloodflow observed is not clear. The bloodflow per gram of ovarian tissue was several times greater than the capillary flow in ovarian tissue as estimated by the 
indicator fractionation technique in ewes (B. P. Setchell, H. M. Radford \& G. M. H. Waites, personal communication) and sows (Rathmacher \& Anderson, 1968). It is possible that a large proportion of the blood collected in the present study passed through ovarian arteriovenous anastomoses. Regression of the corpus luteum in ewes on Days 13 to 14 is apparently not caused by ischaemia unless, contrary to the situation in sows (Rathmacher \& Anderson, 1968), there is a selective reduction in the bloodflow to the corpus luteum.

\section{REFERENCES}

Hettiaratchi, E. S. G. \& Pickford, M. (1968) The effect of oestrogen and progesterone on the pressor action of angiotensin in the rat. F. Physiol., Lond. 196, 447.

Lloyd, S. (1959) The vascular responses of the rat during the reproductive cycle. J. Physiol., Lond. 148,625 .

Moore, N. W., Brown, J. B. \& SmYthe, B. (1965) Oestrogens in the ovarian blood of the ewe. Progr. Abstr. endocr. Soc. Aust., p. 19.

Rathmacher, R. P. \& Anderson, L. L. (1968) Blood flow and progesterone levels in the ovary of cycling and pregnant pigs. Am. F. Physiol. 214, 1014.

Shorr, R. V., McDonald, M. F. \& Rowson, L. E. A. (1963) Steroids in the ovarian venous blood of ewes before and after gonadotrophic stimulation. 7. Endocr. 26, 155. 